\title{
Comparison between Manual and Automatic Identification of Diatoms of Merja Fouarate (Morocco)
}

\author{
Nouzha Chahboune, Mohamed Mehdi, Allal Douira \\ Université Ibn Tofail, Faculté des Sciences, Laboratoire de Botanique, Biotechnologie et de Protection des Plantes, B.P. 133, \\ Kenitra, Marocco
}

\begin{abstract}
The objective of this work is to compare the results of the classical identification of diatoms by optical microscope to the automatic identification of the diatoms. For the first method, we determined the diatoms using an optical microscope and the identification keys.

Concerning the second method, we relied on the processing and analysis of the images to automatically recognize a diatom. Our aim is to compare the results of the manual identification of diatoms with the results of the automatic identification of the same sample. The purpose of this comparison is to verify whether the automaticanalysis can give acceptable results in order to replace the manual determination. We used the Image $j$ software for the development of our program and based on the notion of points of interest and the freeman code.

The results of the determination of the diatoms by optical microscope which lasted more than one month did not exceed 92\% (for 104 species of diatoms 96 species were identified), whereasthe automatic identificationrequires only a few seconds, with much better results (97\%).
\end{abstract}

Keywords- Diatoms, current, identification by microscope, automatic identification, digital image processing, Fouarate, Kenitra, Morocco.

\section{INTRODUCTION}

Rich in thousands of species (Mollo and Noury, 2013), diatoms are diversified into several groups, genera and species, and have been the subject of extensive discussions and divergent opinions concerning the taxonomy and nomenclature (Tolomio, 2011). This diversification presents morphological variations making the identification of diatoms by optical microscope tedious (J. Prigiel and Coste, 1993; Chahboune et al., 2015; Siddour et al., 2007; Manoylov. 2014) and heavy for the uninitiated. Automatic image recognition provides a valuable help both for the identification of diatoms (Chahboune et al., 2015), and especially as a teaching tool to help in identification for new diatomists.

Our study aimed to use two identification methods of the diatoms of the Merja Fouarat, one is the classical method which is based on the identification key using the optical microscope, the other is the automatic method which relies on image analysis and interpretation techniques. The comparison of the two methods allowed us to define to what extent the automatic identification method can meet the challenges encountered in order to identify the diatoms precisely and in a very short time.

\section{MATERIALS AND METHODS}

1- Characteristics of the study sites

Located on the plateau of Mamora, between the pliquaternary clay plain of the Rharb and the granitic, paleozoic, western schisto-sandstone Meseta, the Merja Fouarat is the site of a water table located in the sand and limestone sand of the Plio-Villafranchien (Combe, 1975), with Mediterranean climate and pronounced oceanic influence (sub-humid low temperature, temperate in winter).

The MerjaFouarat is fed by:

- The inflows of Oued Fouarat representing the first important valley of the Mamora plateau (Thauvin, 1966) with a source located at Ras-El-Aîn, about $10 \mathrm{~km}$ south of the Merja;

- Abundant and close rainfalls lead to the exfiltration of natural water from the groundwater (Nassali et al., 2002), accompanied by short duration floods;

- Wastewater from peripheral neighborhoods. 


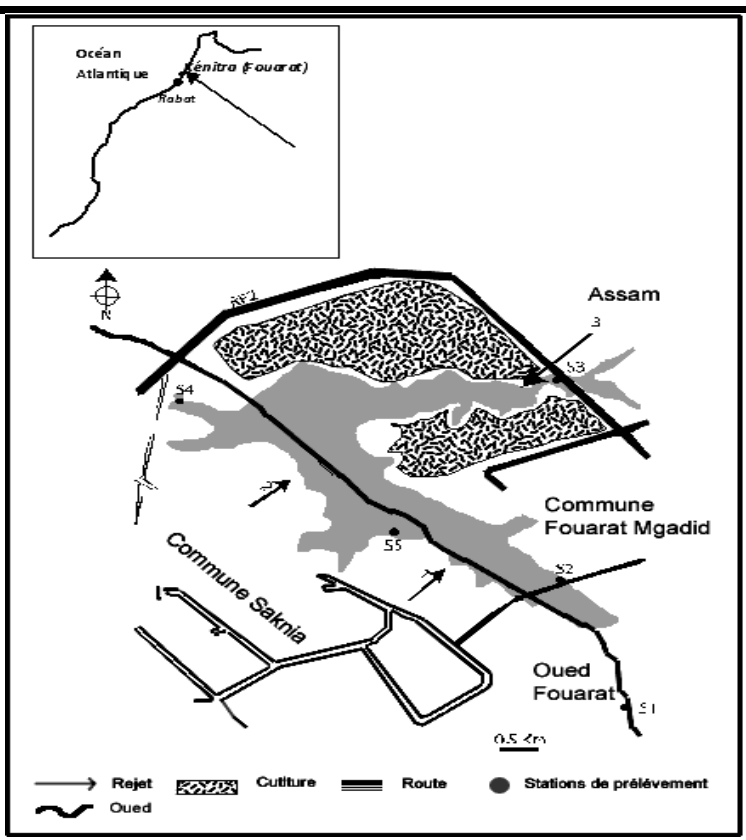

Fig.1: Location of study sites

Caption: S1: Reference station: (Oued Fouarat)

S2, S3, S4 and S5: Stations along the Merja

Fouarat

\section{2- Sampling}

At the five stations, three diatom sampling campaigns were performed. The diatoms were removed by scratching natural substrates using a nylon bristle brush. The samples thus obtained were immediately fixed in formalin (10\%). After a few days of decantation, the diatoms were treated with nitric acid on a hot-plate then mounted with naphrax between the blade and the lamella.

\section{3- Identification of diatoms}

The identification of diatoms by optical microscope was carried out with the help of the work of Germain, 1981; Krammer and Langbertalot, 1986, 1988, 1991a and b). The optical microscopic counts of at least 450 frustules were performed on permanent preparations. The numbers of each taxon were transformed into relative abundance (Chahboune et al., 2011). The automatic identification consisted of a classification from the same sample. This identification relied on the software Image $\mathrm{j}$ (Chahboune et al., 2015), a digital image processing application developed at the National Institute of Health (Wayne, 1997).

\section{RESULTS AND DISCUSSION}

The identification of the diatoms by microscope required an enormous effort both in terms of learning, which lasted five months in order to acquire the skills of a diatomist, and in terms of the determination of the diatoms which lasted longer than a month with a result approaching $92 \%$, for 96 diatom species out of 104. 8 species (Navicula sp 1, Navicula sp2, Navicula sp3, Nitzschia sp1, Nitzschia sp2, Gomphonema sp1, Gomphonema sp2, Surerella) were difficult to classify. Indeed, the particularities of some potentially more complex species are difficult to solve (Tolomio, 2011; Ector and DašaHlúbiková, 2010; Lavoie, 2008; Coste and Ector, 2000).

The automatic identification in turn required a preprocessing phase of the images and the results were around 97\%. The automatic classification work confirms our approach:

- ADIAC teams have achieved good classification rates above $96 \%$ on a much larger sample, even surpassing the results of human experts. (Jalba et al., 2004).

- The work of (Siddour et al., 2007) which consisted in characterizing the contour of the diatoms according to a vector of the Fourier descriptors from a database of diatom images, obtained a good classification rate of $97 \%$. As for (Claudon, 2007), he presented a classification method based also on the windowed Fourier transform, but taking into account the internal structures and the ornamentations of the diatoms. His analysis on a reference sample was approaching $100 \%$.

Therefore, we find that the automatic classification is effective. However, the automatic recognition of diatoms is a long term project because its success requires that the image database be continuously supplied. Clearly, the system we have developed can only identify the diatoms listed. If a diatom does not exist in the database, it will not be recognized. Further work should help fuel the image database.

\section{CONCLUSION}

We can infer that automation has a double contribution: it allows a rapid identification with great success results, and especially allows the novice to avoid a tedious learning.

\section{REFERENCES}

[1] Chahboune N., Mehdi M. \& Douira A., 2015. Identification automatique des diatomées de la Merja Fouarate : Une alternative à la détermination et à la classification manuelle. Journal of Applied Biosciences, 93:8675-8687. 
[2] Chahboune N., Mehdi M. \& Douira A., 2011. Détérioration des écosystèmes aquatiques dans la région du gharb (Maroc): Analyse diatomique .Science lib Éditions Mersenne: volume 3, $\mathrm{N}^{\circ} 110808$ ISSN 2111-4706.

[3] Claudon N. 2007. Automatic classification of diatomies: an approach to the patterns of internal structures. Mémoire présenté à l'université du Québec à Trois-Rivières.Université du Québec

[4] Combe M., 1975: Le bassin Rharb-Maamora. Ressources en eau de la plaine du Rharb et bassins du Maroc atlantique. Notes et Mémoires du Service Géologique, Maroc, $\mathrm{N}^{\circ} 231$.

[5] Coste M. and Ector L., 2000. Diatomées invasives exotiques ou rares en France: Principales Observations effectuées au cours des dernières décennies. Systematics and Geography of Plants, 70(2), 373-400.

[6] Germain H., 1981. Flore des diatomées, Diatomophycées. Paris, Boubée, 444p.

[7] Jalba Andrei C., Michael H.F. Wilkinson \& Jos B.T.M. Roerdink, 2004. Automatic Segmentation of Diatom Images for classification. Microscopy Research and Technique, 65:72-85

[8] Krammer K. \& Langebertalot H., 1986. Bacillariophyceae. Tome 1: Naviculaceae. Semper Bonis Artibus, 876p.

[9] Krammer K \& Langebertalot H., 1988. Bacillariophyceae, Tome 2: Bacillariaceae, Epithemiaceae et Surirellaceae. Semper Bonis Artibus, $596 \mathrm{p}$.

[10] Krammer K \& Langebertalot H., 1991 . Bacillariophyceae. Tome 3: Centrales,Fragilariaceae, Eunotiaceae. Semper Bonis Artibus, 576p.

[11] Krammer K. \& Langebertalot H., $1991 b$. Bacillariophyceae. Tome 4: Achnanthaceae. Semper BonisArtibus, 437p.

[12] Krammer K. \& Langebertalot H., 2000. Bacillariophyceae. Tome 5: Englishand French translation of the Keys. Semper Bonis Artibus, 311p.

[13] Lavoie I., 2008. Guide des diatomées des rivières de l'est de Canada. Presse de l'université de Québec, 2ème trimestre, $450 \mathrm{p}$.

[14] Ector Luc \& Dasa Hlubicova, 2010: Atlas des diatomées des Alpes-Maritimes et de la Région Provence-Alpes-Côte d'Azur. Conseil Général des Alpes-Maritimes, Direction de l'Écologie et du Développement Durable Sous-Direction Ingénierie Environnementale et Expertise Service Eaux et Milieu marin, $393 \mathrm{p}$.
[15]Manndg Vanormelingen P., 2013.An Inordinate Fondness, The Number, Distributions, and Origins of Diatom Species. Journal of Eukaryotic Microbiology, 60: 414-420.

[16] Manoylov K.M., 2014: Taxonomic identification of algae (morphological and molecular): species concepts, methodologies, and their implications for ecological bioassessment. Journal of Phycology, 50: 409-424.

[17] Prygiel J. \& Coste M., 2000. Guide méthodologique pour la mise en œuvre de l'Indice Biologique Diatomées NF T 90-354, Agences de l'Eau-Cemagref.

[18] Siddour A., Nouboud F., Mammass D., Chalifour A., Campeau S., 2007. Classification of diatoms by contour Fourier descriptors. Numéro 4 / Issue 4. Spécial MCSEAI $2006>$ Recherche de formes et vision / Pattern Recognition and Vision http://www.revue-eti.net/document.php?id=1374.

[19] Tolomio C., 2011: Inventaire préliminaire du phytoplancton de la Corse en saison estivale (Baie de Calvi et Golfe de Porto Vecchio). Marinelife, revue.fr, $17: 25-38$. 